\title{
Students' Perception on Reward and Punishment Given by English Teachers Sesmita ${ }^{1}$, Reflinda $^{2}$
}

\author{
${ }^{1}$ State Islamic Institut of Bukittinggi (LAIN) Bukittinggi, e-mail: sesimitamita@gmail.com \\ ${ }^{2}$ State Islamic Institut of Bukittinggi (LAIN) Bukittinggi, e-mail : reflinda88@,gmail.com
}

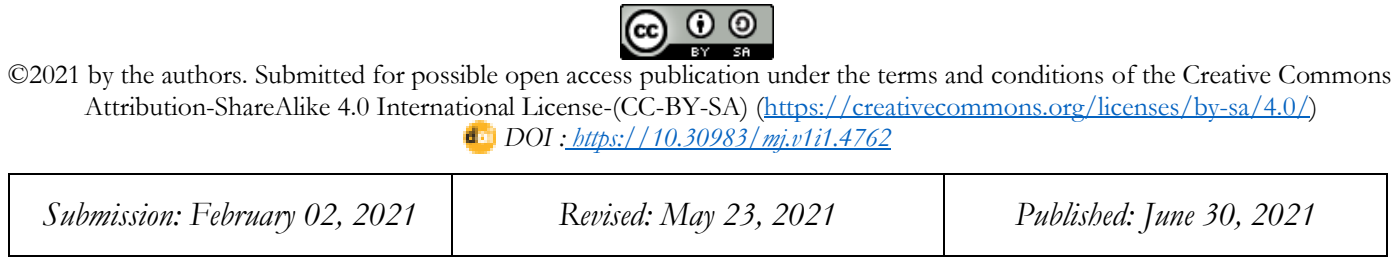

\begin{abstract}
Abstrak
Penelitian ini bertujuan untuk mengetahui persepsi siswa tentang pemberian hadiah dan hukuman yang diberikan oleh guru bahasa inggris di MTs.TI. Candung. Penelitian ini terjadi karena peneliti menemukan beberapa masalah. Beberapa siswa tidak memperhatikan penjelasan guru, beberapa siswa tidak mengerjakan tugas yang diberikan guru dan beberapa siswa suka tidur dan berbicara dengan yang lain selama proses pembelajaran. Desain dari penelitian ini merupakan descriptive kuantitatif. Jumlah populasi sebanyak 134 siswa dan sampel 55 siswa yang dipilih menggunakan purposive sampling technique. Instrument yang digunakan oleh peneliti yaitu angket. Data dikumpulkan dari angket untuk mengetahui persepsi siswa tentang pemberian hadiah dan hukuman yang diberikan oleh guru bahasa inggris di MTs.TI.Candung. teknik analisis data dalam penelitian ini adalah (1) pengumpulan angket siswa, (2) menghitung persentase data, (3) mencari rata-rata, (4) mengkategorikan persepsi berdasarkan table penafsiran. Ada lima pilihan dalam menjawab angket, yaitu kategori sangat setuju, setuju, raguragu, tidak setuju, sangat tidak setuju. Hasil menunjukan bahwa persentase skor persepsi siswa tentang pemberian hadiah sebesar $86,51 \%$. Artinya, siswa memiliki persepsi dalam kategori sangat baik. Selain itu, persentase skor persepsi siswa tentang pemberian hukuman sebesar $68,6 \%$, artinya siswa memiliki persepsi dalam kategori baik untuk aspek ini. Temuan penelitian ini menunjukkan bahwa persepsi siswa terhadap pemberian hadiah yang diberikan oleh guru bahasa Inggris adalah sangat baik dan persepsi terhadap pemberian hukuman yang diberikan oleh guru bahasa Inggris dikategorikan baik.
\end{abstract}

Kata kunci: persepsi siswa, hadiah dan hukuman

\begin{abstract}
This research is aimed to find out the students' perception on reward and punishment given by English teachers at MTs.TI.Candung. This research was conducted because the researcher found several problems. Some students have lack attention of teacher explanation, some of students did not do the tasks given by teacher, some of students tended to converse during learning process. Descriptive quantitative was the method of the research. The population was 134 students and the sample was 55 students and purposive sampling was used as the research sample. The instrument of this research is questionnaire. The data was collected from questionnaire to find out the students' perception on reward and punishment given by English teachers at MTs.TI.Candung. The technique of data analysis in this research is (1) collecting the students' questionnaire, (2) calculating the percentage of the data, (3) the finding mean of the data, (4) categorizing the perception based on table interpretation. There are five options in answering the questionnaire. Those are strongly agree, agree, moderate, disagree, strongly disagree. The result showed that the percentage of score students' perception on reward given by English teachers aspect is $86,51 \%$. It means that students had perception in very good category. Besides, the percentage score of students' perception on punishment given by English teachers is $68,6 \%$. The findings of this study indicate that the students' perception of the gift given by the English teacher is very good and the perception of the punishment given by the English teacher is categorized as good.
\end{abstract}

Keywords: students' perception, reward and punishment

\section{Introduction}

Teacher is one of major components in teaching and learning process. The teacher should bring the students feel enjoyable in the process of teaching and learning. The success of learning 
mainly depend on teacher way and style greatly influence to students. The teacher has the important role in implementing education in order to achieve educational goals. Many teaching strategies can be applied by the teacher. All of these strategies to make the learning process well that it can achieve goal. One of them is to provide reward and punishment to the student in an effort to improve student achievement. According to Nurvauzati (2020) reward and punishment is an important strategies in the learning process, because it has value of motivation and information.

Reward is an educational strategy which can be used to make the students feel happy in learning a language and also it can be used to give motivation to the students for learning better. The reward is a means of repressive education that is fun given to student who excel in teaching, have progress and good behavior, and become role models for companies. Reward one factor that influences student learning outcomes so it is important to describe the reward given by English teacher. Teacher should use reward in order to maintain a positive learning environment and to promote appropriate classroom behaviors. According to Irawati (2016)) reward for student should be real but it does not have to be something expensive. In this case, the teacher's creativity is really needed. So, the teacher can make something special for the students.

According to Irawati (2016)) Punishment is a consequence following a bad behavior that students do in the class. Punishment in the classroom needs to be implemented with care and educated so that students will not do it again. Punishment can be used by the teacher directly when the students do something that is not suitable with the rules of learning in the class. Before using any punishment strategies, it is important to know the appropriate classroom management strategies.

Based on explanation above, giving reward and punishment have various influences to the students' behaviour in which the students will have different perception on reward and punishment given by English teachers. Perception is one of factor that influences students learning process. Every people have different perception about something. The differences perception of individual with each other is like one object, but other people do not like the object. Perception can be grouped by people into different actions. If someone against in negative may be their action will be negative. If the student's perception is positive, it may act the same. Students' perception has necessary implications in behavior to determine how students' behave and interact toward the perceived object.

In supporting this research, the researcher employed some previous studies to make easy in finishing this journal. First, the research was conducted by Nurvauzati putri (2020) about " Reward and Punishment given by the Teacher in Teaching English as Foreign Language in Indonesian Context". The result showed that reason giving reward to enhance students' enthusiasm in learning English and to increase students' motivates in learning process and reason giving punishment to change students' behaviour and to make students' afraid to repeat the same mistakes during learning English. Second, the research was conducted by Galih Prasetyo (2020) about " Teacher's and Student's Perception toward Reward and Punishment in Teaching Writing to First Grade TKR 3 of SMK PGRI Kediri in Academic Year 2019/2020”. The result showed that the application of reward and punishment by the teacher are needed in teaching writing. Meanwhile, this research focuses on students' perception on reward and punishment given by English teachers

Based on the preliminary research by doing observation at MTs.TI.Candung, the researcher found some problem; first some of the students had lack attention of teacher explanation, 
teacher gave reward against the students who are able to answer teacher's questions. Second, some of the students did not do the tasks given by teacher, so that they made double tasks. Third, some of the students tended to converse during learning process, so that they got warning from the teacher. It would be covered in the research by the title "Students Perception on Reward and Punishment Given by English Teachers at MTS.TI.Candung”.

\section{Method}

The design of this research was descriptive quantitative research. According to Margono (2007) quantitative research is a process to get knowledge or information by using numeral data as the tool to get what information which is intended to be known. It means that the researcher collected the data to describe and answer the research question.

In this research, the population was all of the eight grade students at MTS.TI.Candung. The total numbers of the students were 134 students from five classes. The data were collected by using questionnaire. After that, the researchers analyzed the students' answer using Likert Scale as suggested by Morissan (2015).

\section{Results and Discussion}

The items of the question answered by the students were calculated to know the description and percentage of the students' perception on reward and punishment given by English teachers at MTs.TI.Candung. The diagram below showed the percentage of two aspects and each aspect with different level frequency. The description of the data on the students' perception on reward and punishment given by English teachers at MTs.TI.Candung are as follow:

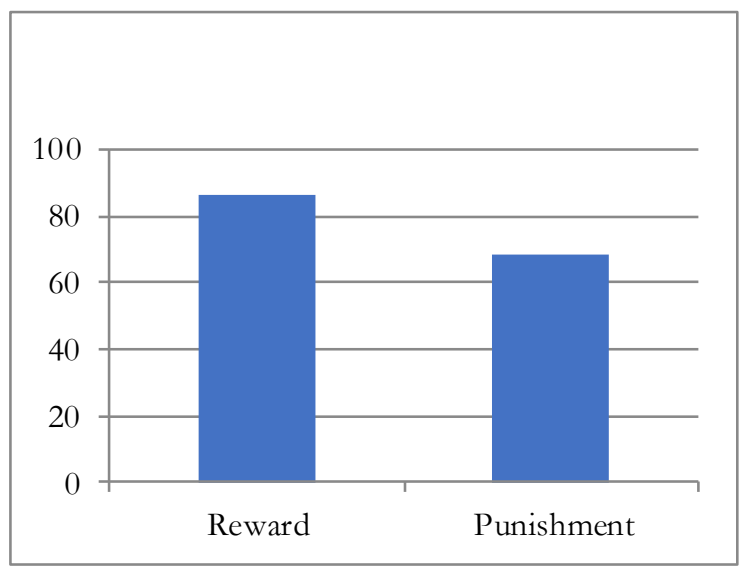

Figure 1. Mean Percentage of Students' Answer

The figure above explains the total percentage of the students' perception on reward and punishment given by English teachers. The highest aspect that was chosen reward (86,81\%), and punishment $(68,6 \%)$.

Then, there were 28 statements which aim to investigate students' perception on reward and punishment given by English teachers at MTs.TI.Candung. The result of students' perception can be presented in the table below.

Table 3 The Result of Students' Perception on Reward and Punishment Given By English Teachers

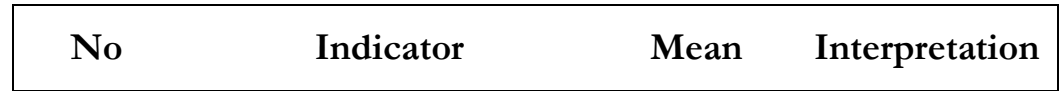




\begin{tabular}{|cccc|}
\hline 1 & Reward & $86,81 \%$ & Very Good \\
\hline 2 & Punishment & $68,6 \%$ & Good \\
\hline
\end{tabular}

The table above indicates that the students' perception on reward in the percentage about reward is $86,81 \%$ (very good) and punishment is $68,6 \%$ (Good). It means that there are differences in students' perceptions towards the rewards and punishments given by the English teacher during teaching and learning activities.

\section{Conclusion}

It is concluded that in general, the students at MTs.TI.Candung have different perception on reward and punishment given by their English teachers. The result showed that the percentage of score students' perception on reward given by English teachers aspect is $86,51 \%$. It means that students had perception in very good category. Besides, the percentage score of students' perception on punishment given by English teachers is 68,6\%. The findings of this study indicate that the students' perception of the gift given by the English teacher is very good and the perception of the punishment given by the English teacher is categorized as good.

\section{References}

S. Jambi, "The Implementation Of Reward And Punishment In Teaching English At Madarussalam Stano Thesis Marlina Nim : 205172823 English Education Study Program Faculty Of Education And Teacher Training State Islamic University," 2021. [Online]. Available: www.iainjambi.ac.id.

M. Sabartiningsih and J. A. Muzakki, "AWLADY: Jurnal Pendidikan Anak Implementasi Pemberian Reward Dan Punishment Dalam Membentuk Karakter Disiplin Anak Usia," vol. 4, no. 1, 2018, [Online]. Available: www.syekhnurjati.ac.id/jurnal/index.php/awlady.

S. Misriyah, "Implementation And Implication Of Reward And Punishment Toward Character Education At Senior High School In Pemalang."

R. Afrila and S. Syahrilfuddin, "Persepsi Siswa Tentang Pemberian Reward Terhadap Motivasi Belajar Siswa Kelas V Sd Muhammadiyah 6 Pekanbaru," J. PAJAR (Pendidikan dan Pengajaran), vol. 4, no. 1, Jan. 2020, doi: 10.33578/pjr.v4i1.7933.

S. A. Sidin, "The Application of Reward and Punishment in Teaching Adolescents," 2021.

I. Indrawati, U. Madako Marzuki, and A. Rinaldy Malik, "Investigating The Effect Of Reward And Punishment On The Student's Learning Achievement And Discipline," English Educ. Art J., vol. 4, pp. 2597-3819, doi: 10.31539/leea.v4i2.1860.

E. Kasyulita, “An Analysis Of Students' Motivation In Learning English After Given Rewards At The Eight Grade Students' Of Smpn 3 Rambah,” J. English Educ., vol. 5, no. 1, 2019.

R. Hapesah, “The Effect of Reward and Punishment in Increasing Students' Motivation to Learn English,” 2020. [Online]. Available: https://journal.iainlangsa.ac.id/index.php/jades.

G. S. Ching, "Looking into the issues of rewards and punishment in students," Int. J. Res. Stud. Psychol., vol. 1, no. 2, Jan. 2012, doi: 10.5861/ijrsp.2012.v1i2.44. 
A. Fatahian Kelishadroky, A. Shamsi, M. Bagheri, and M. Mansorihasanabadi, "The Role of Reward and Punishment in Learning," Int. J. Adv. Biotechnol. Res., vol. 7, pp. 780-788, [Online]. Available: http://www.bipublication.com.

A. İkbal Tuba Şahin Sak, A. Ramazan Sak, and L. Betül Kübra Şahin Çiçek, "The Persistence Of Reward And Punishment In Preschool Classrooms.”

A. Shreeve et al., "Student perceptions of rewards and sanctions," Pedagog. Cult. Soc., vol. 10, no. 2, pp. 239-256, 2002, doi: 10.1080/14681360200200142.

U. Bengkulu, The Importance of the Competence of Language Teachers in Providing Rewards and Punishments in Improving Student Learning Outcomes Noermanzah, vol. 1, no. 1. .

L. Claudiu and C. Langa, "Rewards And Punishments Role In Teacher-Student Relationship From The Mentor's Perspective Train the provider: European Exchange on Training Programmes for Adult Education Provider View project Start în cariera ta!-UPIT (START-UPIT) View project Rewards And Punishments Role In Teacher-Student Relationship From The Mentor's Perspective," 2014. [Online]. Available: https://www.researchgate.net/publication/297890158.

I. Darimi and B. Ismail, "Education 'Jaman Now': Reward and Punishment Review."

J. Kubanek, L. H. Snyder, and R. A. Abrams, "Reward and punishment act as distinct factors in guiding behavior," Cognition, vol. 139, pp. 154-167, Jun. 2015, doi: 10.1016/j.cognition.2015.03.005.

E. Putut Dumiyanto, G. Baqiyudin, M. Arfin Basri, and E. P. Dumiyanto, "Reward And Punishment In Online Learning Pjok Of The Covid-19 Pandemic On Students Of Karangwinongan State School, Mojoagung," doi: 10.21107/Widyagogik/v9i1.

A. Fauzia Rozani Syafei, "Journal of English Language Teaching The Use Of Reward And Punishment To Increase Young Learners' Motivation In Learning English As Foreign Language Adapted To Indonesian Context," J. English Lang. Teach., vol. 5, no. 1, [Online]. Available: http://ejournal.unp.ac.id/index.php/jelt.

M. Sapii Harahap, “Teachers’ Perceptions Of Reward And Punishment And Its Implementation In Learning At Smp It Khairul Imam Medan,” Proceeding Int. Semin. Islam. Stud., vol. 2.

S. Wahyuni Syarifuddin, “Analysis of Reward and Punishment in EFL Classroom,” 2020.

I. Pajarillo-Aquino, "The Effects Of Rewards And Punishments On The Academic Performance Of Students Of The College Of Teacher Education," Int. J. Adv. Res., 2016, [Online]. Available: www.garph.co.uk.

W. M. Lubis, "ELLITE Journal of Education, Linguistics, Literature and Language Teaching Reward And Punishment In English Foreign Language Classroom."

Y. Amalia, S. Wantina, D. Widya, I. Siliwangi, and Y. Com, "The Implementation Of Reward And Punishment Towards Student Perception In English Learning At Ikip Siliwangi," vol. 2, no. 6, 2019.

N. M. S. D. Saraswati, N. M. Ratminingsih, and I. A. L. P. Utami, "Students' and Teachers' Perception on Reward in Online English Teaching Context," J. Educ. Res. Eval., vol. 4, no. 3, pp. 307-314, 2020, [Online]. Available: https://ejournal.undiksha.ac.id/index.php/ JERE.

K. Phungphai and A. Boonmoh, "Students' Perception Towards The Use Of Rewards To Enhance Their Learning Behaviours And Self-Development," doi: 10.30606/jee. 
A. Antonaci, R. Klemke, and M. Specht, "The effects of gamification in online learning environments: A systematic literature review," Informatics, vol. 6, no. 3, Aug. 2019, doi: 10.3390 /informatics6030032.

M. Fuad, E. Suyanto, and U. A. Muhammad, "Can 'Reward and Punishment' Improve Student Motivation?," Eur. Online J. Nat. Soc. Sci., vol. 10, no. 1, pp. 165-171, 2021, [Online]. Available: http://www.european-science.com. 